\title{
Características nutricionales del forraje de mijo perla en cuatro estados fenológicos
}

\section{Nutritive characteristics of pearl millet forage in four phenological stages}

\author{
Jorge Urrutia Moralesa, Antonio Hernández Alatorrea, José Francisco Cervantes \\ Becerraa, Héctor Gámez Vázqueza ${ }^{a}$
}

\begin{abstract}
RESUMEN
El objetivo del presente estudio fue determinar el valor nutritivo del forraje de mijo perla cosechado en diferentes estados fenológicos. El estudio se realizó en condiciones de riego con la variedad ICMV-221 de doble propósito, del que se tomaron muestras en cuatro estados fenológicos: H7) séptima hoja, HB) hoja bandera o última hoja, E) embuche y F) floración. Las muestras se analizaron por NIRS (near infrared spectroscopy) para determinar su contenido de nutrientes y los resultados se analizaron por medio de análisis de varianza dentro de un modelo completamente al azar. El contenido de materia orgánica se incrementó con la madurez $(P<0.003)$, mientras que el contenido de proteína cruda fue mayor $(P<0.005)$ en el estado de séptima hoja. El contenido de carbohidratos no fibrosos no mostró cambios significativos debidos a la edad de la planta $(P>0.05)$, mientras el de fibra detergente neutra (FDN) fue similar $(P>0.05)$ en los cuatro estados fenológicos y el de fibra detergente ácida (FDA) aumentó del estado de $\mathrm{H7}$ al estado de $F(P<0.008)$. El contenido de lignina $(P<0.06)$ y el de lignina ligada a FDN $(P<0.05)$ se elevaron con la edad. La digestibilidad de la materia seca disminuyó $(P<0.0005)$ con la edad de $81.7 \%$ en $\mathrm{H7}$ a $69.0 \%$ en F. Los contenidos de energía tendieron a reducirse con la madurez, aunque no en forma significativa $(P>0.05)$. Se concluye que la edad del forraje de mijo perla al momento del corte afectó significativamente la mayoría de las variables de valor nutritivo estudiadas, siendo los forrajes más tiernos los que mostraron mejores características forrajeras.
\end{abstract}

PALABRAS CLAVE: Forraje, Mijo Perla, Valor nutritivo, Estados fenológicos.

\begin{abstract}
The present study was conducted in order to evaluate the nutritive value of pearl millet forage harvested at different maturity states. The study was made under watering conditions with ICMV-221 two purposes variety. Four samples were taken at each four maturity states: (LS) leaf $7^{\text {th }}$, (FL) flag leaf, (BS) boot stage, and (F) flowering. The samples were analyzed by NIRS (near infrared spectroscopy) to determine the nutrients content and results were subjected to analysis of variance into complete randomly model. Organic matter content increased with maturity $(P<0.003)$, while crude protein content was higher $(P<0.005)$ in $L S$. Non fiber carbohydrates did not show significant changes $(P>0.05)$ with maturity. Neutral detergent fiber (NDF) content was similar $(P>0.05)$ in the four maturity stages, but acid detergent fiber (ADF) content increased $(P<0.008)$ from $L S$ to $F$ stage. Lignin and lignin linked to NDF increased $(P<0.05)$ with age. Dry matter digestibility was reduced $(P<0.0005)$ with age from $81.7 \%$ in LS to $69.0 \%$ in $F$ stage. Energy contents tend to reduce with maturity of forage, but not significant differences were detected $(P>0.05)$. Results indicated that age of pearl millet forage at harvest affected in a significant way almost all parameters of nutritive value. Younger forages showed the best nutritive characteristics.
\end{abstract}

KEY WORDS: Pearl millet forage, Nutritive value, Phenological stages.

En las regiones áridas y semiáridas, la escasez de forraje en las épocas de sequía, origina
In arid and semi-arid regions, the shortage of forage in times of drought, originates recurrent

Recibido el 13 de mayo de 2013. Aceptado el 17 de julio de 2013.

a Campo Experimental San Luis, CIRNE, INIFAP. Km 14.5 Carretera San Luis Potosí-Matehuala. Soledad de Graciano Sánchez, 78430 , San Luis Potosí, México. urrutia.jorge@inifap.gob.mx; jorurrmo@hotmail.com. Correspondencia al primer autor. 
estados recurrentes de subalimentación en los animales de agostadero(1), lo que se refleja en pérdidas de peso, pobre desempeño reproductivo y baja producción general. La producción de forrajes para la suplementación del ganado en el estiaje, constituye una estrategia indispensable para mantener a los animales en un estado nutricional que permita lograr niveles de productividad aceptables. Sin embargo, la errática distribución de lluvias(2) junto con la presencia de heladas tempranas origina siniestros frecuentes en los cultivos tradicionales, cuando son cosechados en estados de grano lechoso para ensilarlos. Debido a que estos cultivos requieren de periodos de más de tres meses y medio, es raro que logren alcanzar el estado óptimo para la cosecha. Esta situación hace indispensable el uso de forrajes de ciclo más corto y que además tengan la posibilidad de ser cosechados en estos estados tempranos de desarrollo, manteniendo un nivel nutricional elevado.

El mijo perla ha mostrado ser un forraje de buena calidad nutritiva, equiparándose e incluso superando frecuentemente la calidad del forraje del maíz y el sorgo, tanto en digestibilidad como en contenido de proteína(3). Así mismo, es un forraje que presenta buen comportamiento de rebrote después de ser cortado en estados tempranos de desarrollo(4). A pesar de las ventajas que muestra el mijo perla, es importante determinar la posibilidad de cosecharlo en forma muy temprana, ya sea para ensilarlo o para henificarlo, con el fin de reducir el periodo en que el cultivo permanece expuesto a las condiciones ambientales.

El estado de madurez en que el forraje es cosechado y ensilado constituye uno de los factores que más afecta el valor nutritivo y la producción total de forraje $(5,6,7,8)$. En la medida en que aumenta la madurez de las plantas ocurren cambios en la composición química del forraje, como aumento de la materia seca y reducción de la proteína cruda(9). Recientemente se observó que el forraje cosechado entre los estados de embuche y floración mostraron mejor states of sub-feed in rangeland animals(1), which is reflected in weight loss, poor reproductive performance and low overall production. The production of forage for livestock supplementation in the dry season is a strategy for keeping animals in nutritional condition enabling to achieve acceptable levels of productivity. However, the erratic distribution of rainfall(2) together with the presence of early frost originates common claims in traditional crops, when they are harvested in states of milky grain for silage. Since these crops require periods of more than $3 \mathrm{mo}$, it is rare that they will achieve the optimum state for the harvest. This makes necessary the use of forages of shorter cycle than has the possibility to be harvested in these early periods of development, while maintaining a high nutritional level.

Pearl millet has proved to be a good quality nutritious forage, being analogous and even surpassing frequently the quality of maize and sorghum forage, in digestibility and protein content(3). Likewise, it is a plant that shows good regrowth after being cut in early stages of development(4). Despite the advantages of pearl millet, is important to determine the possibility of harvesting it very early, either for silage or for hay, in order to reduce the period in which the crop remains exposed to the environmental conditions.

The state of maturity in which the fodder is harvested and ensiled constitutes one of the factors that most affect the nutritional value and total forage production(5-8). In so far as the maturity of the plants increases, the chemical composition of fodder changes, the dry matter increases and crude protein decreases(9). Recently, it was observed that forage harvested between stages of booting and flowering showed better nutritive value than harvested at grain stage (4). However, there is little information available on the nutritive value of pearl millet in earliest stages of maturity. Therefore, it is necessary to determine the variations that occur during the process of maturation of the plant to identify the more 
valor nutritivo que los cosechados en estado de grano(4). Sin embargo es poca la información que hay disponible sobre el valor nutritivo del mijo perla en estados más tempranos de madurez. Por ello, es preciso determinar las variaciones que ocurren durante el proceso de maduración de la planta para determinar en qué etapas fenológicas es más conveniente cosechar el forraje. El presente estudio se diseñó con el fin de evaluar el valor nutritivo del forraje de mijo perla cosechado en diferentes estados de desarrollo, bajo el supuesto de que la calidad nutricional del forraje es igual o mejor en estados de desarrollo previos a la floración.

El estudio se realizó durante el ciclo primaveraverano, en condiciones de riego, en el Campo Experimental San Luis, del INIFAP, ubicado en el municipio de Soledad de Graciano Sánchez, SLP, localizado a $22^{\circ} 14^{\prime} 03^{\prime \prime} N$ y $100^{\circ} 53^{\prime} 11^{\prime \prime}$ O, y altitud de 1,835 msnm. El clima se considera seco estepario frío BsKw (wi)(10). La temperatura media anual es de $16.8^{\circ} \mathrm{C}$ con una mínima de $10{ }^{\circ} \mathrm{C}$ y una máxima de $26.3^{\circ} \mathrm{C}$; la precipitación pluvial anual es de $332.2 \mathrm{~mm}(11)$.

Se utilizó una superficie de $500 \mathrm{~m}^{2}$ (24 m de largo x 25 surcos de ancho) de mijo Perla de la variedad ICMV-221 de doble propósito, sembrada el 14 de abril aplicando el paquete sugerido por el INIFAP para condiciones de riego(12). Cuando el $10 \%$ de las plantas alcanzó el estado de floración, se procedió a realizar el muestreo de forraje. Para ello, se eliminaron cuatro metros en las cabeceras y cinco surcos en los laterales, quedando una parcela útil de $16 \mathrm{~m} \times 15$ surcos, la cual se dividió en cuatro parcelas de $8 \mathrm{~m} \times 7$ surcos cada una. En cada parcela se obtuvo una muestra de cada uno de los cuatro estados de madurez: séptima hoja (H7), hoja bandera (HB), embuche (E) y floración (F). Cada muestra estuvo constituida por el tallo principal de cinco plantas seleccionadas al azar entre las plantas disponibles que estaban en el estado fenológico correspondiente. Para su conservación, las muestras se picaron en molino para forraje verde y se secaron en horno a $65^{\circ} \mathrm{C}$ durante $48 \mathrm{~h}$. convenient phenological stages for harvesting. The present study was designed to evaluate the nutritional value of pearl millet forage harvested at different stages of development, under the assumption that the nutritional forage quality is equal or better in stages of development prior to flowering.

The study was conducted during the springsummer, by irrigation, at the Experimental Station San Luis, INIFAP, located in the municipality of Soledad de Graciano Sánchez, SLP, at $22^{\circ} 14^{\prime} 03^{\prime \prime} \mathrm{N}$ and $100^{\circ} 53^{\prime} 11^{\prime \prime} \mathrm{W}$, and 1,835 masl. The climate is considered dry cold steppe BsKw (wi)(10). The average annual temperature is $16.8^{\circ} \mathrm{C}$ with a minimum of 10 ${ }^{\circ} \mathrm{C}$ and a maximum of $26.3^{\circ} \mathrm{C}$; annual rainfall is of $332.2 \mathrm{~mm}(11)$.

An area of $500 \mathrm{~m}^{2}$ (24 m long x 25 wide furrows) of pearl millet ICMV-221 dual purpose variety, was planted on April 14, applying the guide suggested by INIFAP for irrigation conditions(12). Forage sampling was performed when $10 \%$ of the plants reached the flowering stage. Four meters at the headwaters and five furrows in the side were eliminated, leaving a useful plot of $16 \mathrm{~m} \times 15$ rows, which were divided into four plots of $8 \mathrm{~m} \times 7$ rows each. In each plot a sample of each of the four maturity stages was obtained: leaf seventh (LS), flag leaf (FL), boot stage (BS) and (F) flowering. Each sample consisted of the main stem of five plants selected randomly among the available plants that were in the corresponding phenological stage. For conservation, samples were sting in a mill for green fodder and dried in oven at $65^{\circ} \mathrm{C}$ for $48 \mathrm{~h}$.

Samples were sent to the laboratory to determine the contents of crude protein, soluble protein, degradable protein, protein linked to acid detergent fiber, acid detergent fiber (ADF), neutral detergent fiber (NDF), lignin, lignin linked to neutral detergent fiber, non-fibrous carbohydrate, starch, carbohydrates soluble in water, carbohydrates soluble in ether, raw fat, in vitro digestibility at $30 \mathrm{~h}$, total digestible 
Las muestras se enviaron al laboratorio para determinar los contenidos de proteína cruda, proteína soluble, proteína degradable, proteína ligada a fibra detergente ácido, proteína ligada a fibra detergente neutro, fibra detergente ácida, fibra detergente neutra, lignina, lignina ligada a fibra detergente neutro, carbohidratos no fibrosos, almidón, carbohidratos solubles en agua, carbohidratos solubles en éter, grasa cruda, digestibilidad in vitro a las $30 \mathrm{~h}$, total de nutrientes digestibles, energía neta de lactancia, energía neta de mantenimiento, energía neta de ganancia, energía metabolizable, valor relativo del forraje, cenizas, fósforo, calcio, magnesio, potasio, cloruros y azufre. Las muestras se analizaron en un equipo NIRS (Near Infrared Reflectance Spectroscopy) modelo 5000 de la marca FOSS en el laboratorio de la Forrajera de Ganaderos de Aguascalientes S.A. de C.V (FOGASA). Para la determinación de los valores nutricionales se utilizaron ecuaciones de predicción y bases de datos generadas por la "Dairy One Cooperative Incorporation". En la calibración del equipo se siguió el siguiente procedimiento: a) selección de muestras al azar b) análisis por métodos primarios, c) lectura de espectros en de las mismas muestras en el equipo NIRS, d) ajuste de las curvas y e) validación de las curvas (comparación de los resultados obtenidos con ambos métodos).

Los resultados se analizaron por ANOVA por medio de un diseño completamente al azar con cuatro tratamientos y cuatro repeticiones cada uno. Cuando se encontraron diferencias al nivel de 0.05 , se aplicó la prueba de Tukey para comparación de medias en el mismo nivel. Para los análisis se utilizó el paquete estadístico JMP Star Statistics, Ver 4.0.3.

El contenido de materia orgánica se incrementó con la madurez $(P<0.003)$, de $88.9 \%$ en estado de séptima hoja a $92.24 \%$ en floración. El contenido de proteína cruda fue mayor en el estado de séptima hoja que en los demás estados fenológicos $(P<0.005)$, mientras que el de proteína degradable se redujo gradualmente con la madurez de 69.2 a $59.5 \%(P<0.006)$. nutrients, net energy of lactation, net energy of maintenance, net energy of gain, metabolizable energy, relative value of forage, ash, phosphorus, calcium, magnesium, potassium, chloride, and sulfur. The samples were analyzed by NIRS (Near Infrared Reflectance Spectroscopy) using an equipment FOSS model 5000 in the Cattlemen Laboratory of Forage, Aguascalientes S.A. de C.V (FOGASA). Prediction equations and databases generated by the "Dairy One Cooperative Incorporation" were used for determination of nutritional values. For the equipment calibration the following procedure was followed: a) Selection of random samples b) Analysis by primary methods, c) Reading of spectrum in the same samples in the NIRS computer, d) Adjusting curves and e) Validation of the curves (comparison of the results obtained with both methods).

The results were analyzed by ANOVA using a completely randomized design with four treatments and four replications each. When obtaining differences at 0.05 levels, the Tukey test was applied for comparison of means. JMP Star Statistics, ver. 4.0.3 statistical package was used for the analysis

Organic matter content increased with maturity $(P<0.003)$, from $88.9 \%$ in LS to $92.24 \%$ at flowering. The crude protein content was higher in LS than other stages, while that of degradable protein was gradually reduced phonologically $(P<0.005)$ with the maturity from 69.2 to $59.5 \%$ $(P<0.006)$. Non-fibrous carbohydrate content showed no significant changes due to the plant age $(P>0.05)$, but the raw fat decreased with the age of the plant $(P<0.008)$. Although the NDF content was similar $(P>0.05)$ in the four phenological stages, FDA was affected by the maturity of the plants $(P<0.008)$, being higher in samples harvested in FL and BS, that in the other two. Both, lignin content $(P<0.06)$ and lignin linked to NDF $(P<0.05)$ tended to rise with age of the forage, being maximum in the stage of flowering (Table 1 ). 
CARACTERÍSTICAS NUTRICIONALES DEL FORRAJE DE MIJO PERLA EN CUATRO ESTADOS FENOLÓGICOS

Cuadro 1. Contenido de humedad, materia seca, proteína, carbohidratos, grasa y fibra en forrajes de mijo perla cosechados en cuatro estados fenológicos (Prom $\pm D E$ )

Table 1. Contenido de humedad, materia seca, proteína, carbohidratos, grasa y fibra en forrajes de mijo perla cosechados en cuatro

\begin{tabular}{lccccc}
\hline Estado de madurez & Hoja 7 & Hoja bandera & Embuche & Floración & Prob. \\
\hline $\mathrm{n}$ & 4 & 4 & 4 & 4 & \\
$\mathrm{MS}(\%)$ & $94.3 \pm 1.0$ & $94.8 \pm 1.8$ & $95.0 \pm 0.5$ & $95.7 \pm 0.4$ & $>, 35$ \\
$\mathrm{MO}(\% \mathrm{MS})$ & $88.9 \pm 0.4^{\mathrm{a}}$ & $89.7 \pm 1.4^{\mathrm{a}}$ & $90.2 \pm 1.0^{\mathrm{a}}$ & $92.2 \pm 0.7^{\mathrm{b}}$ & $<, 003$ \\
$\mathrm{PC}(\% \mathrm{MS})$ & $15.4 \pm 0.8^{\mathrm{a}}$ & $12.9 \pm 0.7^{\mathrm{b}}$ & $12.7 \pm 0.4^{\mathrm{b}}$ & $12.2 \pm 1.0^{\mathrm{b}}$ & $<, 0005$ \\
$\mathrm{PD}(\% \mathrm{de} \mathrm{PC})$ & $69.2 \pm 2.2^{\mathrm{a}}$ & $63.5 \pm 4.4^{\mathrm{ab}}$ & $63.2 \pm 2.9^{\mathrm{ab}}$ & $59.5 \pm 1.9^{\mathrm{b}}$ & $<, 006$ \\
$\mathrm{CHNF}(\% \mathrm{MS})$ & $15.3 \pm 2.2$ & $16.6 \pm 2.1$ & $16.8 \pm 1.1$ & $18.1 \pm 1.2$ & $>, 15$ \\
$\mathrm{GC}(\% \mathrm{MS})$ & $2.2 \pm 0.1^{\mathrm{a}}$ & $1.3 \pm 0.6^{\mathrm{b}}$ & $1.4 \pm 0.3^{\mathrm{b}}$ & $1.4 \pm 0.2^{\mathrm{b}}$ & $<, 008$ \\
FDA (\% MS) & $40.1 \pm 1.7^{\mathrm{a}}$ & $44.1 \pm 2.6^{\mathrm{b}}$ & $44.9 \pm 0.6^{\mathrm{b}}$ & $42.5 \pm 1.2^{\mathrm{ab}}$ & $<, 008$ \\
FDN (\% MS) & $61.6 \pm 2.3$ & $63.9 \pm 4.2$ & $64.2 \pm 0.8$ & $65.1 \pm 1.2$ & $>, 25$ \\
LIG (\% MS) & $5.2 \pm 0.4^{\mathrm{a}}$ & $5.9 \pm 1.7^{\mathrm{ab}}$ & $6.4 \pm 0.3^{\mathrm{ab}}$ & $7.2 \pm 0.5^{\mathrm{b}}$ & $<, 06$ \\
LLFDN (\%FDN) & $7.1 \pm 2.6^{\mathrm{a}}$ & $9.2 \pm 2.4^{\mathrm{ab}}$ & $10.0 \pm 0.5^{\mathrm{ab}}$ & $11.1 \pm 0.6^{\mathrm{b}}$ & $<, 05$ \\
\hline
\end{tabular}

Materia seca (MS), materia orgánica (MO), proteína cruda (PC), proteína degradable (PD), carbohidratos no fibrosos (CHNF), grasa cruda (GC), fibra detergente ácido (FDA), fibra detergente neutro (FDN), lignina (L) y lignina ligada a fibra detergente neutro (LLFDN). Valores con distintas letras en la misma línea difieren $(P<0.05)$.

El contenido de carbohidratos no fibrosos no mostró cambios significativos debidos a la edad de la planta $(P>0.05)$, no así el de grasa cruda que disminuyó con la edad de la planta $(P<0.008)$. Aunque el contenido de FDN fue similar $(P>0.05)$ en los cuatro estados fenológicos, el de FDA fue afectado por la madurez de las plantas $(P<0.008)$, siendo mayor en los forrajes cosechados en los estados de hoja bandera y embuche, que en los otros dos. Tanto el contenido de lignina $(P<0.06)$ como el de lignina ligada a FDN $(P<0.05)$ tendieron a elevarse con la edad del forraje, siendo máximo en el estado de floración (Cuadro 1).

La digestibilidad de la materia seca disminuyó $(P<0.005)$ con la edad de la planta de $81.7 \%$ en el estado de $\mathrm{H} 7$ a $69.0 \%$ en floración. Sin embargo, el TND no se vio afectado $(P>0.05)$, al igual que los valores energéticos. El valor relativo del forraje fue mayor $(P<0.05)$ en el forraje cosechado en estado de $\mathrm{H} 7$ (Cuadro 2).

Los contenidos de cenizas y minerales se presentan en el Cuadro 3. Los contenidos de
Digestibility of dry matter decreased $(P<0.005)$ with the age of the plant from $81.7 \%$ in LS to $69.0 \%$ in BS. However, the total of digestive nutrients was not affected ( $P>0.05)$, as well as the energetic values. The relative value of the forage was higher $(P<0.05)$ for forage harvested in LS stage (Table 2).

The contents of ash and minerals are presented in Table 3. The contents of ash, phosphorus, and potassium were higher in the more tender forage, but the rest of the minerals showed no changes due to the age of the forage at harvesting time. The contents of $\mathrm{Ca}, \mathrm{P}, \mathrm{Mg}$, and $\mathrm{K}$ in the forage pearl millet at any of the stages of maturity were adequate to meet the requirements for ruminants(13).

Previous studies noted that forage pearl millet can be harvested on BS or $F$, with similar nutritional value or greater than the more mature forage(4). The present study was conducted to evaluate the possibility to harvest it in the earliest stages of development, including previous states to the boot stage or the spike 
Jorge Urrutia Morales, et al. / Rev Mex Cienc Pecu 2014;5(3):321-330

Cuadro 2. Digestibilidad in vitro de la materia seca, total de nutrientes digestibles, contenido energético y valor relativo forrajero de forrajes de mijo perla cosechados en cuatro estados fenológicos (Prom $\pm \mathrm{DE}$ )

Table 2. Digestibilidad in vitro de la materia seca, total de nutrientes digestibles, contenido energético y valor

\begin{tabular}{lccccc}
\hline Estado de madurez & Hoja 7 & Hoja bandera & Embuche & Floración & $\mathrm{F}$ \\
\hline $\mathrm{n}$ & 4 & 4 & 4 & 4 & \\
DIVMS (\%) & $81.7 \pm 3.1 \mathrm{a}$ & $72.5 \pm 2.6 \mathrm{bc}$ & $74.5 \pm 1.3 \mathrm{~b}$ & $69.0 \pm 2.8 \mathrm{c}$ & $<, 0002$ \\
TND (\%) & $55.0 \pm 0.8$ & $52.7 \pm 3.6$ & $52.2 \pm 2.1$ & $52.7 \pm 1.3$ & $>, 25$ \\
ENI (Mcal Kg-1) & $1.1 \pm 0.04$ & $1.0 \pm 0.12$ & $1.0 \pm 0.04$ & $1.0 \pm 0.03$ & $>, 15$ \\
Enm (Mcal Kg-1) & $1.0 \pm 0.02$ & $1.0 \pm 0.13$ & $0.9 \pm 0.07$ & $0.9 \pm 0.04$ & $>, 20$ \\
ENg (Mcal Kg-1) & $0.5 \pm 0.02$ & $0.4 \pm 0.12$ & $0.4 \pm 0.07$ & $0.4 \pm 0.03$ & $>, 15$ \\
EM (Mcal Kg-1) & $2.1 \pm 0.03$ & $1.9 \pm 0.16$ & $1.9 \pm 0.09$ & $1.9 \pm 0.04$ & $>, 10$ \\
VRF & $87.2 \pm 1.9 \mathrm{a}$ & $80.0 \pm 7.9 \mathrm{ab}$ & $78.0 \pm 1.6 \mathrm{~b}$ & $79.5 \pm 2.4 \mathrm{ab}$ & $<, 05$ \\
\hline
\end{tabular}

Digestibilidad in vitro de la materia seca a las 30 horas (DIVMS), total de nutrientes digestibles (TND), energía neta de lactancia $(E N I)$, energía neta de mantenimiento $(E N m)$, energía neta de ganancia $(E N g)$, energía metabolizable $(E M)$, valor relativo del forraje (VRF). Valores con distintas letras en la misma línea difieren $(P<0.05)$.

Cuadro 3. Contenido de cenizas y algunos minerales en forrajes de mijo perla cosechados en cuatro estados fenológicos (Prom $\pm \mathrm{DE}$ )

Table 3. Contenido de cenizas y algunos minerales en forrajes de mijo perla cosechados en cuatro estados

\begin{tabular}{lccccc}
\hline Estado de madurez & Hoja 7 & Hoja bandera & Embuche & Floración & $\mathrm{F}$ \\
\hline $\mathrm{n}$ & 4 & 4 & 4 & 4 & \\
$\mathrm{C}(\%)$ & $11.1 \pm 0.5 \mathrm{a}$ & $10.3 \pm 1.5 \mathrm{a}$ & $9.8 \pm 1.0 \mathrm{a}$ & $7.8 \pm 0.7 \mathrm{~b}$ & $<, 003$ \\
$\mathrm{P}(\%)$ & $0.4 \pm 0.02 \mathrm{a}$ & $0.4 \pm 0.06 \mathrm{ab}$ & $0.4 \pm 0.04 \mathrm{ab}$ & $0.3 \pm 0.05 \mathrm{~b}$ & $<, 02$ \\
$\mathrm{Ca}(\%)$ & $0.6 \pm 0.09$ & $0.5 \pm 0.13$ & $0.6 \pm 0.04$ & $0.5 \pm 0.04$ & $>, 50$ \\
$\mathrm{Mg}(\%)$ & $0.2 \pm 0.02$ & $0.2 \pm 0.04$ & $0.2 \pm 0.05$ & $0.3 \pm 0.06$ & $>, 50$ \\
$\mathrm{~K}(\%)$ & $3.3 \pm 0.31 \mathrm{a}$ & $3.2 \pm 0.66 \mathrm{a}$ & $3.0 \pm 0.35 \mathrm{a}$ & $1.9 \pm 0.31 \mathrm{~b}$ & $<, 004$ \\
Cloruros $(\%)$ & $0.9 \pm 0.16$ & $0.7 \pm 0.16$ & $0.8 \pm 0.24$ & $0.7 \pm 0.08$ & $>, 35$ \\
$\mathrm{~S}(\%)$ & $0.2 \pm 0.06$ & $0.1 \pm 0.02$ & $0.2 \pm 0.02$ & $0.2 \pm 0.02$ & $>, 35$ \\
\hline
\end{tabular}

Cenizas $(\mathrm{C})$, fósforo $(\mathrm{P})$, calcio $(\mathrm{Ca})$, magnesio $(\mathrm{Mg})$, potasio $(\mathrm{K})$, cloruros $(\mathrm{Cl})$ y azufre $(\mathrm{S})$. Valores con distintas letras en la misma línea difieren $(\mathrm{P}<0.05)$.

cenizas, fósforo y potasio fueron mayores en los forrajes más tiernos, pero el resto de los minerales no mostraron cambios debidos a la edad del forraje al momento del corte. Los contenidos de $\mathrm{Ca}, \mathrm{P}, \mathrm{Mg}$ y $\mathrm{K}$ en el forraje de mijo perla en cualquiera de los estados de madurez fueron adecuados para cubrir los requerimientos de los rumiantes(13). or panicle formation. The results indicate that cut into LS has better nutritional value than harvested at more advanced stages of maturity.

During the vegetative growth stages, the plant consists mainly of leaves and tender stems, whose nutrients contents are high, while the degree of lignification of the cell walls is low. 
En estudios previos se había observado que el forraje de mijo perla puede ser cosechado en estado de embuche o floración, con valores nutritivos similares o mayores al del forraje de mayor madurez(4). El presente trabajo se realizó para evaluar la posibilidad de cosecharlo en estados más tempranos de desarrollo, incluyendo estados previos al embuche o formación de la espiga o panoja. Los resultados indican que el forraje cortado en estado de séptima hoja presenta mejor valor nutritivo que el cosechado en estadios más avanzados de madurez.

Durante las etapas de desarrollo vegetativo, la planta está conformada principalmente por hojas y tallos tiernos, cuyos contenidos de nutrientes son altos, mientras que el grado de lignificación de las paredes celulares es bajo. En estos estados de desarrollo, la proporción hoja:tallo es elevada, debido a que las hojas se han formado completamente, pero los tallos no se han alargado aún(14). En estos estados de desarrollo, la acumulación de materia seca está casi completamente confinada a las hojas, por lo que la mayor parte de los nutrientes están contenidos en ellas(14). Dado que las hojas contienen gran parte de la proteína contenida en la planta y la digestibilidad de las hojas generalmente es elevada en comparación con la de los tallos, la calidad del forraje en estos estados vegetativos tiende a ser más elevada que la que se observa en estados más avanzados de desarrollo.

Entre el estado de séptima hoja y hoja bandera ocurrieron cambios sustanciales en la planta. Por un lado, el contenido de proteína descendió drásticamente (15.38 a $12.95 \%$ ), mientras que la FDN y la FDA aumentaron marcadamente. En forma similar, tanto la proteína cruda como la proteína degradable mostraron reducciones importantes en este lapso. Probablemente, esto se debió a que entre estos dos estados de madurez ocurren cambios fisiológicos de importancia, caracterizados por la transición del desarrollo vegetativo a la etapa reproductiva(14). Hasta este momento, la mayor acumulación de
In these stages of development, the proportion leaf:stem is high, since the leaves have fully formed, but stems have not yet elongated(14). In these stages, the accumulation of dry matter is almost completely confined to leaves, so most of the nutrients are contained therein(14). Since the leaves contain much of the protein of the plant and digestibility of the leaves is generally high in comparison with the stalks, the quality of the forage in these vegetative stages tends to be higher than that observed in more advanced stages of development.

Between LS and FL occurred substantial changes. On the one hand, protein content decreased drastically (15.38 to $12.95 \%$ ), while the NDF and the FDA increased sharply. Similarly, both the crude protein and degradable protein showed significant reductions in this period. This was probably due to physiological changes of importance, characterized by the transition from the vegetative development to the reproductive stage(14) occurring between these two maturity stages. So far, greater accumulation of dry matter in the plant takes place in leaves, whereas the internodal elongation of stems is still slow. Later, in the stage of $\mathrm{FL}$, leaves end up its growth and plant growth is due to the elongation of the stem. In this stage, basal leaves begins its senescence(14). Along with these changes, it also initiates the formation of the panicle. These changes involve the translocation of nutrients from the leaves to the stem and the reproductive system. The stem elongation involves a process of the cell walls lignification, which explains the gradual fiber increases with the age of the plant.

In $\mathrm{FL}$ or last leaf, vegetative growth ends and begins development of the panicle within the lamina of the leaf flag(14). From the BS, when the panicle begins to form, maturity starts, and forages are gradually reducing the proportion leaf:stem(15). Insofar as maturity advance, the leaves are losing nutrients, that are translocated to the grain(7), which explains the gradual reduction in the nutritional value( $(9)$. Together with the reduction in the proportion 
materia seca en la planta tiene lugar en las hojas, mientras que la elongación internodal de los tallos aún es lenta. Posteriormente, en el estado de hoja bandera, las hojas terminan su crecimiento y el crecimiento de la planta se debe a la elongación del tallo. En este estado, las hojas basales comienzan su senescencia(14). Junto con estos cambios, inicia también la formación de la panícula. Estos cambios suponen la translocación de nutrientes de las hojas hacia el tallo y el aparato reproductor. La elongación de los tallos implica un proceso de lignificación de las paredes celulares, lo que explica los aumentos graduales de fibra registrados con la edad de la planta.

En el estado de hoja bandera o última hoja, el desarrollo vegetativo culmina y comienza el desarrollo de la panoja dentro de la lámina de la hoja bandera(14). A partir del estado de embuche, cuando la panoja comienza a formarse, se inicia la etapa de madurez de la planta, en la que los forrajes van reduciendo gradualmente la proporción hoja:tallo(15). En la medida en que avanza la madurez, las hojas van perdiendo nutrientes, que son traslocados al grano(7), lo cual explica la reducción gradual en el valor nutritivo que generalmente se observa(9). Junto con la reducción en la proporción hoja:tallo que se verifica con la madurez(15), ocurre un proceso de lignificación en las paredes celulares de los órganos estructurales(16), lo que origina que gradualmente se reduzca la digestibilidad de las hojas y tallos, dado que la digestibilidad de los forrajes disminuye con el aumento en la concentración de lignina(17). De esta forma, el mayor contenido de lignina junto con el incremento en el contenido de FDN observado en las plantas más maduras, explica la reducción observada en la digestibilidad(17).

El contenido de carbohidratos no fibrosos también aumentó en forma paralela con el incremento en la FDN y FDA durante el proceso de maduración, aunque no en forma significativa, lo cual sugiere que en estas etapas las hojas continúan con su función fotosintética leaf:stem(15), occurs a lignification in the cell walls of the structural bodies(16), which causes that gradually the digestibility of the leaves and stems is reduced as forage digestibility decreases with the increase in the lignin concentration(17). In this way, the higher lignin content along with the increase in NDF observed in the most mature plants, explains the reduction in digestibility(17).

Non-fibrous carbohydrate content also increased in parallel with the increase in the NDF and FDA during the maturation process, but not in a significant way, which suggests that in these stages leaves are continuing with its photosynthetic function in a way still very active. Increases in NDF levels and non-fibrous carbohydrates, were offset by the reduction in the digestibility that explains why the energy input had remained relatively stable in the four phenological stages evaluated.

For farming with limited resources in the semiarid region of Northern Mexico, where forage is usually produced under rainfed conditions, is important to ensure forage surplus for the dry season. In the present study the production of nutrients per hectare was not determined, since only the main stems of each plant was harvested. Given the tendency of the pearl millet to produce large amount of secondary stems, which are usually harvested along with the primary, made of little interest to determine the production of nutrients based solely on the production of primary stems. Previous studies found, that the production of dry matter and nutrients is lower when the forage is harvested in BS, compared to the grain dough-milky stage(4). Despite the lower production, the large capacity of regrowth showed by the pearl millet, along with the advancement in the harvest, made it possible to make a second cut about $30 \mathrm{~d}$ later, which offset the lower yield of cutting early(4).

In conclusion, the age at harvesting of forage pearl millet significantly affect most of the nutritional values of variables studied, being 
de manera aún muy activa. Los incrementos en los contenidos de FDN y de carbohidratos no fibrosos, se vieron contrarrestados por la reducción en la digestibilidad, lo que ayuda a explicar el que el aporte de energía se haya mantenido relativamente estable en los cuatro estados fenológicos evaluados.

En las explotaciones ganaderas de bajos recursos de la región semiárida del norte de México, donde el forraje generalmente se produce en condiciones de temporal, es importante garantizar la cosecha de forraje para la época de estiaje. En el presente estudio no se determinó la producción de nutrientes por hectárea, debido a que sólo se cosecharon los tallos principales de cada planta. Dada la tendencia que presenta el mijo perla a producir gran cantidad de tallos secundarios, los cuales suelen cosecharse junto con los primarios, hace de poco interés determinar la producción de nutrientes basado únicamente en la producción de tallos primarios. En estudios anteriores se determinó que la producción de materia seca y de nutrientes es menor cuando el forraje se cosecha en estado de embuche, en comparación con el cosechado en estado de grano masosolechoso(4). No obstante la menor producción, la gran capacidad de rebrote que muestra el mijo perla, junto con el adelanto en la cosecha, hizo posible realizar un segundo corte alrededor de 30 días después, con lo que se compensó el menor rendimiento del corte temprano(4).

En conclusión, la edad del forraje de mijo perla al momento del corte afectó significativamente la mayoría de las variables de valor nutritivo estudiadas, siendo los forrajes más tiernos los que mostraron mejores características forrajeras. El contenido de proteína y la digestibilidad in vitro de la materia seca fueron mayores en los estados de séptima hoja y hoja bandera, sin embargo, el valor energético no se vio afectado. La posibilidad de cosechar el forraje de mijo perla en cualquiera de estos estados fenológicos permite adecuar el manejo de la cosecha a las condiciones climáticas. Esto es importante para los productores de bajos recursos de los the more tender forage which showed best characteristics. Protein content and dry matter in vitro digestibility were higher in stages of leaf seventh and flag leaf; although, the energy value was not affected. The possibility of harvesting the pearl millet forage in any of these phenological stages allows harvest management to adapt to climatic conditions. This is important for producers of low-resource systems of rangeland in the semi-arid region of North and Central Mexico, because it allows them to reduce the risks of losses by early frost and ensure the availability of good quality forage for the dry season.

End of english version

sistemas de agostadero de la región semiárida del norte y norte-centro de México, pues les permite reducir los riesgos de pérdidas por heladas tempranas y garantizar la disponibilidad de forraje de buena calidad para la época de estiaje.

\section{LITERATURA CITADA}

1. Echavarría CFG, Gutiérrez LR, Ledesma RRI, Bañuelos VR, Aguilera SJI, Serna PA. Influencia del sistema de pastoreo con pequeños rumiantes en un agostadero del semiárido Zacatecano. I Vegetación nativa. Téc Pecu Méx 2006;44:203217.

2. Villanueva DJ, Loredo OC, Hernández RA. Requerimientos hídricos de especies anuales y perennes en la zona media y altiplano de San Luis Potosí. Folleto Técnico No 12. Instituto Nacional de Investigaciones Forestales, Agrícolas y Pecuarias. Campo Experimental San Luis. 2001.

3. Hernández AJA, Zavala GF, Jasso CC, Ventura RE, Martínez GMA, Durán LK. Adaptación y rendimiento del mijo perla en los temporales de San Luis Potosí. Folleto Científico No 3. Instituto Nacional de Investigaciones Forestales, Agrícolas y Pecuarias. Campo Experimental San Luis. 2009.

4. Urrutia MJ, Hernandez AA, Altamira EA, Beltran LS, Gámez $\mathrm{VH}$, Diaz GMO. Nutritional characteristics of silage and hay of pearl millet at four phenological stages. J Anim Vet Adv 2011;10(11):1378-1382.

5. Cummuns DG. Quality and yield of corn plants and component parts when harvested for silage at different maturity stages. Agron J 1970;62:781-784. 
6. Cummunis DG. Yield and quality changes with maturity of silages-type sorghum. Agron J 1981;73:988-990.

7. Center CF, Jones GD, Carter MT. Dry matter accumulation and depletion in leaves, stems, and ears of maturating maize. Agron J 1970;62:535-537.

8. Filya I. Nutritive value and aerobic stability of whole crop maize silage harvested at four stages of maturity. Anim Feed Sci Technol 2004;116:141-150.

9. Vilela HH, Vilela RA, Vieira PF, Andrade GA, Evangelista AR, de Souza-Almeida GB. Valor nutritivo de silagens de milho colhido em diversos estádios de maturação. R Bras Zootec 2008;37:1192-1199.

10. García E. San Luis Potosí. En: Modificaciones al sistema de clasificación climática de Köppen. UNAM. Instituto de Geografía, 1973.

11. Medina GG, Díaz PG, Loredo OC, Serrano AV, Cano GMA. Estadísticas climatológicas básicas del estado de San Luis Potosí (período 1961-2001). Libro Técnico No 2. Instituto Nacional de Investigaciones Forestales, Agrícolas y Pecuarias. Campo Experimental San Luis. 2005.
12. Hernández AJA, Zavala GF, Martínez GMA, Jasso ChC, Ventura $\mathrm{RE}$, Durán LK. Tecnología para producir forraje de mijo perla en San Luis Potosí. Folleto para Productores No 3. Instituto Nacional de Investigaciones Forestales, Agrícolas y Pecuarias. Campo Experimental San Luis. 2007.

13. National Research Council. Nutrient requirements of beef cattle. 7th ed. Washington, D.C: National Academy Press; 2000.

14. Maiti RK, Bidinger FR. Growth and development of the pearl millet plant. ICRISAT Res Bull No. 6. 1981.

15. Albrecth KA, Wedin WF, Buxton DR. Cell-wall composition and digestibility of alfalfa stems and leaves. Crop Sci 1987; 27:735-741.

16. Jung $\mathrm{HJ}$, Vogel KP. Lignification of switchgrass (Panicum virgatum) and big bluestem (Andropogon gerardi) plant parts during maturation and its effect on fiber degradability. J Food Sci Agric 1992;59:169-176.

17. Van Soest PJ. Nutritional ecology of the ruminants. First edition Oregon, USA O and Books, Inc; 1982. 